\title{
Three Early Galician-Portuguese Poets: Airas Moniz d' Asme, Diego Moniz, Osoir’ Anes. A Critical Edition
}

\author{
Rip Cohen \\ Johns Hopkins University
}

\begin{abstract}
:
This paper presents a critical edition of Airas Moniz d'Asme, Diego Moniz, and Osoir'Anes, the first three named poets in the Cancioneiro da Biblioteca Nacional (Colocci-Brancuti) whose poems have survived. Many of these cantigas have proved quite difficult for textual critics and interpreters. This edition attempts to provide a needed step forward: a fresh reading with critical apparatus, notes, metrical analysis, and English translations.
\end{abstract}

Key words:

Galician-Portuguese philology and poetics, cantigas d'amor, textual criticism, metrics, historical grammar.

\section{Resumo:}

Este trabalho apresenta uma edição crítica de Airas Moniz d'Asme, Diego Moniz e Osoir' Anes, os primeiros poetas cujos poemas sobreviveram no Cancioneiro da Biblioteca Nacional (Colocci-Brancuti). Muitas destas cantigas têm-se mostrado extremamente dificeis para a crítica textual e para a interpretação literária. Esta edição pretende ultrapassar algumas das dificuldades encontradas, oferecendo uma nova leitura destas cantigas, com aparato crítico, notas, análises métricas e traduções para o inglês.

\section{Palavras-chave:}

Filologia e poética galego-portuguesa, cantigas d'amor, crítica textual, métrica, gramática histórica.

In the Cancioneiro da Biblioteca Nacional (siglum B), alias Colocci-Brancuti, the first three named poets (following the lais), and among the earliest, are Airas Moniz d'Asme, Diego Moniz, and Osoir' Anes, although this was not the original order and some texts were lost $^{1}$. We might learn something about the development of

1 On the poets, see Monteagudo 2008 (315-416); Oliveira (1994: 316-317, 326-327, 398-399); Gonçalves (1976: 55) on the situation in the Tavola Colocciana; Ferrari (1979: 94-95) on codicological matters; Ferrari (1993) on the manuscript in general; ruminations in Miranda (2004: 49-52). 
Galician-Portuguese lyric by studying their work - mainly cantigas d'amor, although two feature a woman's voice. But many textual and interpretative problems in these poems have remained unsolved.

These cantigas - nine and three fragments- were first transcribed by E. Molteni (1880). Using that transcription, C. Michaëlis edited them in her Cancioneiro da Ajuda (1904: I, 637-657)2. This edition was reviewed by O. Nobiling (1907: 371372; 1909: 202-203) and H. R. Lang (1908: 306-308), both of whom made several important corrections and observations. That was a golden age. Next, A. Cotarelo y Valledor (1933: 17-25) tried his shaky hand at Osoir' Anes. J. P. Machado and E. P. Machado (1949-1964: I, 43-58; hereinafter "Machado") printed these poems in what is neither a transcription nor a critical edition, with errors too numerous to count. Recently, G. Videira Lopes (2002: 22-23) assayed a song of Airas Moniz d'Asme to no avail, and J. C. Ribeiro Miranda (2004: 139-164) emitted an edition of the three poets that reverses nearly every advance made a hundred years ago. Since these are early thirteenth century cantigas copied 300 years later in Rome in a manuscript separated from the original sources by intermediate copies, it is not surprising that there are problems or that interpreters find themselves perplexed ${ }^{3}$. After all, we only have this one late source for some difficult poems. But no help can come from the stubborn defense of corrupt readings, the effacement of sound ones, or conjectures launched from a void.

This is a fresh critical edition with metrical analysis and notes. The apparatus is as concise as possible. The notes explain editorial decisions and attempt to clarify problematic words and passages. An English translation is appended. The editorial conventions followed are mainly those set out before (Cohen 2003: 37-43) ${ }^{4}$. But here I mark with an underline those places where word-final and word-initial vowels collide and meter allows only one syllable (pudi_aver, ela_estar). On finding this

2 Pellegrini (1928) took on Osoir' Anes 1. Rey Somoza (1998) has edited Diego Moniz (sed non vidi).

3 See Michaëlis (1904: II, 525); Gonçalves (1993), Indini (1993); Lopes (2002: 22-23); Miranda (2004: 85-87) for expressions of perplexity. A recent interpretation of Osoir' Anes in Muniz (2002).

4 Some things to note relative to the norms proposed in Ferreiro, M. / Martínez Pereiro, C. P. / Tato Fontaíña, L. (2007): < > for additions; mha (helpful for scanning) not mia; tẽer not teer (in $A$ and $T o$ tils are rarely lacking); onrrar, salrrá (normal spellings) not onrar, salrá; fez mi not fez-mi; volo not vo-lo; but pois la not poisla; poren not por en (poren and én can rhyme in the same strophe, and do not form a dobre); perder vos ei not perder-vos-ei; but achá-la an, devede-lo (where verb and pronoun are fused). I have regularized the use of the cedilha without noting the manuscript readings. A few tonic object pronouns are accented: mí (Osoir' Anes 1, vv. 4, 6) and vós (Osoir' Anes 8, v. 8); but not following a preposition. Latin is used in the critical apparatus: corr. $=$ correxit corrected; delevit deleted; def. = defendit defended; hic locavit placed here; distinxi I divided (punctuated/accented); supplevi I supplied; delevi I deleted; scripsi $\mathrm{I}$ wrote; fort. = fortasse maybe; fort. $\mathrm{x}$ scribendum maybe $x$ should be read; om. $=$ omittit $(\mathrm{B})$ omits; $c f .=$ confer compare. 
sign, the reader can implement the conflation (Parkinson 2006) in various ways (though not by hiatus): elision of the final vowel of the first word; diphthongization by means of a semivowel; fusion of two identical vowels; and absorption of the initial vowel of the second word (aphaeresis) . $^{5}$. All confrontations between word-final and word-initial vowels which are not so marked can be assumed to be instances of hiatus.

I hope this edition will help stimulate study of the questions these cantigas pose. The notes are philological, not literary commentary, although sometimes they deal with interpretation. But any critical edition presupposes - and depends on- an overall interpretation. As L. Stegagno Picchio (1982: II, 318) writes, "Il est bien impossible de reconstituer un texte, d'y apporter des corrections, sans l' avoir parfaitement compris, sans l'avoir interprété, dans le sens le plus vaste et le plus précis du terme." Madvig could not have put it better ${ }^{6}$. Not all of poetics is textual criticism. But textual criticism is all poetics.

5 For the terminology see Parkinson: "The metrical terms under discussion [scil. elision, synaloepha, dipthongization, absorption] are better seen as a single metrical process by which two or more syllables function metrically as a single syllable, a process I will label conflation" (Parkinson 2006: 116).

6 "Itaque omnia, quae in bono enarratore, eadem in critico esse debent" (a textual critic must have all the same abilities as a good interpreter; Madvig 1871: I, 95-96). 


\section{Airas Moniz d'Asme}

$1=$ B 6 (f. 11r)

Pois mi non val d' eu muit' amar

a mha senhor, nen a servir,

nen quan apost' eu sei negar

amor que $l^{\prime}$ ' ei <e m'> encobrir

dela, que me faz $<$ sen $>$ perder,

ca mho non pode $<\mathrm{n}>$ entender,

ja eu chus non a negarei;

vel saberán de quen tort' ei:

Da que á melhor semelhar

de quantas no mund' ome vir,

e mais $<$. . . . falar $>$

das que ome falar oír;

non vola ei chus a dizer,

$<$ ca $>$ quen quer $x$ ' a pode_entender;

ja chus seu nome non direi;

ca afeito mh a nomeei.

E quen ben quiser trastornar

per todo o mund', e ferir,

mui festinho xi_a pod' achar;

ca, por vos ome non mentir,

non á ela tal parecer

con que s' assi possa_asconder;

per como a eu dessinei,

achá-la an, cousa que sei.

Os que me soían coitar

foi lhes mha senhor descobrir;

ja mh ora leixarán folgar,

ca lhis non podia guarir,

ca ben lhela fiz conhocer,

por que me non quis ben fazer;

e tenho que ben me vinguei, pois la_en concelho_avergonhei. 
$4 \mathrm{O}$ amor $B$ : O delevi $\quad<\mathrm{e}>$ Michaëlis $\quad<\mathrm{m}$ '> supplevi encobrir scripsi : ancobrir $B:<\mathrm{e}>\mathrm{a}$ 'ncobrir Michaëlis 5 dela scripsi : Eela $B$ : a ela Michaëlis $\quad<$ sen $>$ supplevi $\mathbf{6}$ ca scripsi : Que $B . \quad$ pode $<\mathrm{n}>$ entender Michaëlis : pode entender B $\quad \mathbf{1 0}$ quanta $<\mathrm{s}>$ no Michaëlis : quanta e no $B \quad \mathbf{1 1}<$ mansa sabe falar> Michaëlis (manso Nobiling) $\quad \mathbf{1 4}<\mathrm{ca}>$ supplevi pode entender $B$, Michaëlis $\mathbf{1 6}$ afeyto $B$ : a feito Michaëlis 18 todo o mund' e Monteagudo : tedeo munde $B$ : tod'o mund $<0>$, e Michaëlis 19 xi-a Michaëlis : xha $B \quad \mathbf{2 5}$ os] or $B$ : corr. Michaëlis 26 foi] fai $B$ : corr. Michaëlis 27 lhela $B$ : lhe'-la Michaëlis : lh' ela Machado $\mathbf{3 2}$ poyslla en $B \quad$ avergonhei scripsi : auey guey $B$

$2=$ B 7 (f. 11r-v)

"Mha senhor, vin vos rogar, por Deus, que ar pensedes de mi, que en gran vagar trouxestes e tragedes; e cuido m' avergonhar; se vos prouguer, devedes oj' a mha barva a onrrar, que sempr' onrrada sol andar; e vós non mh a viltedes."

"Cavaleiro, aviltar-

$<$ la $>$ nunca m' oíredes, mais leixemos ela_estar . . . . -edes

. . . . . - ar

e desso que dizedes-

sol non penso de vos amar, nen pensarei, a meu cuidar, mais desto que veedes."

"Mha senhor, eu vos direi de mi como façades:

o por que vos sempr' amei, per ren non mho tenhades, e sempre vos servirei; se m' oj' avergonhades, fazede como sabor ei, e dade m' al i, e ir m' ei, e non me detenhades." 
"Cavaleiro, non darei;

pero, se vos queixades,

mui ben vos conselharei:

ide vos, que tardades;

ca, por que vos deterrei

$\mathrm{u}$ ren non adubades?

pero desejos averei

de vós, e endurar mhos ei

atá quando_ar venhades."

"Mha senhor, a meu saber,

mais aposto seria

quererdes por min fazer

como_eu por vós faria;

ca eu por tanto d' aver

nunca vos deterria;

mais non poss' eu dona veer

que assi and' a meu prazer

como lh' eu andaria."

3 en $\operatorname{tam} \operatorname{gram} B: \operatorname{tam}$ delevi $\quad \mathbf{5}$ m'] meu $B:$ eu delevi $\quad \mathbf{7}$ oj' a Michaëlis : Oio $B$ : oje Miranda a onrar Michaëlis : e ouirar $B \quad \mathbf{8}$ ouirada $B$ : corr. Michaëlis $\mathbf{9}$ mi-a viltedes Michaëlis : mha uiltedes $B$ : mh aviltedes Machado $\mathbf{1 0}$ aviltar Lang: ia uiltar $B:$ ja aviltar Michaëlis $\quad \mathbf{1 1}<\mathrm{la}>$ supplevi nunca $<\mathrm{ja}>$ Miranda moyredes $B: \mathrm{m}$ '<a $>$ oíredes Michaëlis $\mathbf{1 2}$ ia ela estar $B$ : ia delevit Lang (ela 'star vel ela_estar) $\quad$ 13-14 om. $B \quad \mathbf{1 5}$ hic locavi $\quad \mathbf{1 7}$ meu] men $B \quad 22$ ren] pem $B \quad 23$ sempu9 $B \quad 24$ oj'] oy $B \quad \mathbf{2 6}$ dade m' al i distinxi : da de mali $B$ : dade mal Michaëlis : dade mal i Miranda $\mathbf{2 8}$ non $<_{0}>$ Michaëlis $\quad 32$ ca Michaëlis : Que $B \quad 35$ enduray $B \quad 37$ meu $]$ men $B \quad 38$ seeria $B \quad 44$ prazer Michaëlis : plazer $B \quad \mathbf{4 5}$ comolh'u ?B

\section{Diego Moniz}

$1=\mathrm{B} 8(\mathrm{f} .11 \mathrm{v})$

Deus, que pouco que sabia

eu, en qual viço vivia,

quand' era $<\mathrm{c}>$ on mha senhor,

e que muito me queixava

dela (por que non pensava

Revista Galega de Filoloxía, ISSN 1576-2661, 2010, 11: 11-59

Data de recepción: xaneiro de 2009 | Data de aceptación: marzo de 2009 
de min), e non gradecia a Deus qual ben mi fazia en sol me leixar veer o seu mui bon parecer.

Mais en gran sandez andava

eu, quando me non pagava

de con tal senhor viver,

e que melhor ben queria;

e m' end' ora pagaria;

mais esto_a min, quen mho dava?-

este ben, que non m' entrava:

non ouvess' oj' eu melhor,

e vivess' a tal sabor!

Mais logo m' ar mataria

un cor que ei de folia

mui comprid $<0>$ e d' amor,

que per poucas m' ar matava;

quand' eu mha senhor catava,

en tal coita me metia

que conselho non sabia

eu de min, como fazer

por dela mais ben aver.

Mais, se eu nunca cobrava

o viç' en que ant' estava,

saber lh' ia ben sofrer

seu amor, e nembrar m' ia

que $<$ sen $>$ ela non podia

viver, quand' alhur morava,

tan muito a desejava,

mais eu con este pavor

seria bon sofredor.

2 en] eu $B \quad 3<\mathrm{c}>$ on] on $B$ : corr. Michaëlis $\mathbf{7}$ ben mi] beumi $B$ : ben me Michaëlis $\mathbf{1 0}$ fort. sandeç'; sed cf. CSM 94.55 13 queria scripsi : q'rriã $B:$ querria $\quad 14$ e] A $B:$ corr. Michaëlis 15 a min Michaëlis : anñ $B \quad \mathbf{1 6}$ que non m' entrava Michaëlis : queno nõ entraua $B \quad \mathbf{1 7}$ non] Nono $B$ : corr. Michaëlis 18 e vivess' a scripsi : Eu messen $B$ : e ouvess' eu Michaëlis 21 comprid<0 $>$ e Michaëlis : conpride $B \quad 32$ q' ela nõ podia uiuer $B \quad<\operatorname{sen}>$ Nobiling $\quad 33$ viver hic locavit Nobiling 
$2=\mathrm{B}[8$ bis $]($ f. $11 \mathrm{v})$

Se soubess' a mha senhor como_a mi prazeria

d' eu morrer, pois la non ei, log' eu non morreria;

ca, pero me ben non quer, amor me mostraria,

por me fazer a meu pesar viver,

quand' eu sabor ouvesse de morrer.

E se lhi fossen dizer com' eu esto dizia,

logo sei que mha senhor por min demandaria

1 como a mi scripsi : comomami $B \quad$ prazeria Michaëlis : plazeria $B \quad 2 \operatorname{logueu} B \quad$ moreria $B \quad 3$ monstraria $B$ : corr. Michaëlis 4 por] Lor $B$ : corr. Michaëlis meu] men $B$

\section{Osoir' Anes}

$1=$ B 37 (f. 14r)

Min pres forçadament' Amor

e fez mi_amar que $<$ n $>$ nunc' amou,

e fez mi tort' e desamor

que mí a tal senhor tornou,

e vejo que mal baratei

que mí a tal senhor tornei, que non sabe que é amar

e sabe_a omen penas dar.

Que forçad' oje_e sen sabor

en no mundo vivendo vou,

ca nunca pudi_aver sabor

de min nen d' al, des que foi sou, se non dela, e que farei? 
por que pregunto? ca eu sei:

viver ei, se de min pensar,

ou morrer, se min non amar.

Quen quer x' esto pode veer, e mais quen mego vid' over, que non ei ja sen nen poder de m' emparar dũa molher, a mais mansa que nunca vi, nen mais sen sanha, pois naci; $\mathrm{ve}<\mathrm{e}>$ d' ora se estou mal, que m' emparar non sei de tal,

Ca sõo tan en seu poder

que $\mathbf{s}<\mathrm{e}>$ end' al fazer quiser

non o poderei eu fazer

se me Deus én poder non der

contra ela, que eu servi,

qual dou a ela sobre min,

que nunca eu soub' amar al

erg' ela que mi faz < gran $>$ mal.

2 que $<\mathrm{n}>$ Michaëlis : que $B \quad 4$ que scripsi : quen $B \quad$ mí a tal distinxi : mhatal $B$ : mi-a tal Michaëlis : miña tal Cotarelo y Valledor $\quad \mathbf{6}$ mí a tal distinxi : mha tal $B:$ mi-a tal Michaëlis : miña tal Cotarelo $y$ Valledor 10 en no $B$ : eno Michaëlis $\mathbf{1 5}$ viver ei Michaëlis : Viuerey $B \quad \mathbf{1 8}$ uidouer $B$ : vid' ou $<\mathrm{v}>\mathrm{er}$ Michaëlis 20 dũa] dña $B$ : corr. Michaëlis 23 ve $<\mathrm{e}>$ d' Michaëlis : ued $B \quad 25$ sõo Michaëlis : son $B \quad 26 \mathrm{~s}<\mathrm{e}>$ end' Michaëlis : ssend $B \quad \mathbf{2 8}$ me Deus én distinxi : mend's en $B$ : m' ende Deus Michaëlis 30 mĩ $B$ : mi Michaëlis 32 erguela $B$ : ergo ela Michaëlis <gran> supplevi

$2=$ B 38 (f. 14r)

Sazon é ja de me partir

de mha senhor, ca ja temp' ei

que a servi, ca perdud' ei

o seu amor, e quero m' ir;

mais pero direi lh' ant' assi:

"Senhor, e que vos mereci?

ca non foi eu depois peor

des quando guaanhei voss' amor? 
$\mathrm{E}<\mathrm{a}>$ veredes a sentir

camanha mingua vos farei,

e ve $<$ e $>$ redes, eu o sei,

como poss' eu sen vós guarir,

e diredes depois por min:

'Mesela, por que o perdi?

e que farei quando s' el for

15

alhur servir outra senhor?

Estranha mengua mi fará

tal que per ren non poss' osmar

como sen el possa estar;

de min $\mathrm{ra}<\mathrm{n}>$ curado salrrá

e terrán mho por pouco sen

que a tal omen non fiz ben;

a dona que mho receber

cõmigo se pode perder.

Cada que me lh' eu assanhar,

a meu osm', e lhi mal disser,

se mho logo_a tolher oer

mha vezĩa_e mho sussacar,

maa vezĩa per será;

mais non xi vol' a sentir á,

ca non quer' eu filhar o seu

nen lh' ar querrei leixar o meu.",

6 mereci Michaëlis : merea B $\quad \mathbf{9}<\mathrm{a}>$ veredes Michaëlis : ueredes $B \quad \mathbf{1 1} \mathrm{ve}<\mathrm{e}>$ redes Michaëlis : ueredes $B \quad 13$ mĩ $B$ : mi Michaëlis 19 fort. el<e $>$ possa_estar 20 racurado $B$ : corr. Michaëlis salrá Michaëlis : solhira $B$ : sol irá Miranda 23 mi-o Michaëlis : m eu $B$ : meu Miranda 26 osm'e Michaëlis : osmo $B \quad 27$ mi-o Michaëlis : mha $B \quad$ a tolher distinxi : atolh $B$ : acolher Michaëlis 28 e scripsi : o $B$ : ou Michaëlis mi-o sussacar Michaëlis : mha suffacar $B \quad 29$ maa vezĩa scripsi : maõ vezĩo $B \quad \mathbf{3 0}$ vol' a sentir á distinxi : uola sentira $B$ : vo-lo sentirá Michaëlis

$3=$ B 39 (f. 14v)

Eu, que nova senhor filhei, mal me soube d' afan guardar, 
pois ela nunca soub' amar, atal senhor que vos direi; mais pero direi lh' ũa vez

que faça o que nunca fez.

Quen omen sabe ben querer

ja mais <mal $>$ servid' én será, ca bõa dona vi eu ja

por amar mil tanto valer;

poren lhi direi ũa vez

que faça o que nunca fez.

8 ja Michaëlis : ca $B \quad<$ mal> supplevi

$4=$ B 40 (f. 14v)

Cuidei eu de meu coraçon

que me non podesse forçar, pois me sacara de prison, ed ir comego i tornar, e forçou m' ora nov' amor

e forçou me nova senhor, e cuido ca me quer matar.

E pois me_assi desemparar ũa senhor foi, des enton $\mathrm{e}<\mathrm{u}>$ cuidei ben per ren que non podesse mais outra cobrar; mais forçaron mh os olhos meus e o bon parecer dos seus, e o seu preç' e un cantar

que lh' oí u a vi estar en cabelos, dizend' un son; mal dia non morri enton ante que tal coita levar qual levo, que non vi maior nunca, ond' estou a pavor de $\operatorname{mort}<\mathrm{e}>$, ou de lho mostrar. 
$\mathbf{4}$ ed ir distinx. Monteagudo : edit $B$ : de ir Michaëlis $\quad \mathbf{1 0} \mathrm{e}<\mathrm{u}>$ cuidei Michaëlis : e cuideu $B$ : e def.

Lang 16 son] soy $B$ : corr. Michaëlis 19 non Michaëlis : nũca $B \quad 20$ nunca Michaëlis : q $\sim 1$ leuo $B \quad 21$ mort<e $>$ ou Michaëlis : morton $B$

$5=$ B $40($ fols. $14 \mathrm{v}-15 \mathrm{r})$

E por que me desamades, a melhor das que eu sei? cuid' eu ren i non gãades eno mal que por vós ei; pola ira_en que mh andades tan graves dias levei; dereit' ei, que da ren que mais amei, daquela me segurades:

de vós; e certas, sabhades, muit' amor non desejei, e se vós end' al cuidades ben leu tort' én prenderei; e, por Deus, nõ-no façades, ca por vós me perderei; conort' ei en que pouco durarei se mais de min non pensades.

De muitos son preguntado de que ei este pesar,

e a min pesa_aficado de quen me vai demandar; ei log' a buscar, sen grado, razon por me the salvar, e guardar $\mathrm{m}$ ' ei deles, e $\mathrm{ra}<\mathrm{n}>$ curar e andar i come nembrado.

Ali me ven gran cuidado depois que me vou deitar, pero sõo mais folgado, 
que thi non ei de falar;

jasco deles alongado

que me non ouçan queixar;

tal amar

podedes mui ben jurar

que nunca foi d' omen nado.

Ũa ren vos juraria,

e devede-lo creer,

que ja mais non amaria,

se desta posso viver;

quando vós, que ben queria,

tan sen razon fui perder;

que prazer

avedes de me tolher

meu corpo, que vos servia?

Ca me non receberia

aquel que me fez nacer,

nen eu non vos poderia

atal coita padecer,

ca per ren non poderia;

pois me deit' a dormecer,

entender

no vosso bon parecer

a valer me deveria.

2 a mlhor $B$ : ai! melhor Michaëlis $\quad \mathbf{3}$ gaades $B \quad \mathbf{8}$ que $B$ :fort. ca scribendum $\mathbf{9}$ segurades Michaëlis : segudides $B \quad \mathbf{1 1}$ muit' scripsi : Ouir $B$ : que Nobiling, Lang $\mathbf{2 0}$ pesar Cotarelo y Valledor : penssar $B$ : pensar Michaëlis. $\quad 25$ e a guardar $B$ : a delevi $\quad 26$ e] illeg. $\quad$ racurar $B \quad \mathbf{3 0}$ sõo Michaëlis : scõm $B$ : soon Miranda $\quad \mathbf{4 9}$ atal distinxi : a tal $B$, Michaëlis $\quad \mathbf{5 0}$ poderia] fort. viveria; $c f . v .48 \quad 52$ e entender $B$ : e delevi $\mathbf{5 4}$ deveria Michaëlis : diuiria $B$

$6=$ B 41 (f. 15r)

Vós, mha senhor, que non avedes cura

de m' ascoitar nen de me ben fazer,

ca non quis Deus nen vós nen mha ventura,

a que m' eu nunca pudi defender,

quero vos eu de mha coita dizer: 
mal ei por vós, mui maior ca morrer, se me non val Deu ou vossa mesura perder m' ei eu, e vós en me perder,

perder vos ei, que vos tan muito dura de mal com' eu por vós ei a sofrer, e que non sei de vós aver rancura, pero $\mathrm{m}$ ' en coita fazedes viver, e que vos ei por amor a tẽer quanto de mal me fazedes sofrer; tod' est' eu faço_e non faço cordura

pois me vós non queredes gradecer.

9 perder Michaëlis : perda $B \quad \mathbf{1 1}$ aver senõ rãcura $B$ : senõ delevit Michaëlis $\quad \mathbf{1 3}$ teer $B \quad \mathbf{1 4}$ sofrer $B$ : prender Nobiling (cf. v. 10) : fort. aver

$7=\mathrm{B} 43$ (f. 15r)

Ei eu tan gran medo de mha senhor que nunca lh' ouso nulha ren dizer, e veed' ora de qual ei pavor, de quen non sabe matar nen prender, nen dẽostar, nen bravo responder,

nen catar

5 de ostar B : corr. Michaëlis

$8=$ B 42 (f. 15r)

Par Deus, fremosa mha senhor, macar me fazedes pesar, ei vos ja sempr' a desejar enos dias que vivo for; ca m' ar poderedes fazer, quando ar quiserdes, $p r<$ azer $>$

4 enos $B: \operatorname{nos}$ Michaëlis dias en que $B:$ en delevi $\quad \mathbf{6} \mathrm{p}<$ razer $>$ Michaëlis : $\mathrm{p} r$ ? 


\title{
Notes $^{7}$
}

\author{
Airas Moniz d' Asme 1 \\ $a^{8} b^{8} a^{8} b^{8} c^{8} c^{8} d^{8} d^{8} \quad(x 4)$ ar ir er ei \\ Unissonans. Rep. 107:3. See Canettieri and Pulsoni 2003: 139-140.
}

1-7: a complex period, built on syntactic suspense. A tripartite causal clause (vv. 1-5) -whose third element is subdivided (3-4) and then followed by a relative clause (v. 5) and an explanatory clause (v. 6)- leads up to the first independent verb (v. 7): pois mi non val d'... amar /... nen ...servir / nen quan apost'eu sei negar / ... e m' encobrir / dela (que...), (ca...),/... non ...negarei.

4 amor que lh' ei <e m'> encobrir: $B$ 's reading, $O$ amor quelhey ancobrir, does not make sense here. Instead of ancobrir Michaëlis wants $e_{-} a_{-}$encobrir, with conjunction and preposition. But phonology and metrics then become impossible (Nobiling): three vowels cannot occupy one syllable. The article is not required with amor (Lang 1894: 115-116), even when modified by a relative clause: juran que morren con amor que an (Johan Baveca; Zilli 1977: 77); Meogo 3, v. 1 con amor que lh' eu dei; Dinis 53, v. 5 con amor que a forçava. With the deletion of $o$, the syntax has one more syllable to develop, allowing for both the $e$ Michaëlis wants and the reflexive pronoun $m e$-needed for the construction encobrirse de (see next note): "... how deftly I can cover up (from others) / my love of her, and hide my feelings (e m'encobrir) / from her" (vv. 3-5).

5 dela: Michaëlis corrected Eela (B) to a ela, which is fine by itself (see Stegagno Picchio 1968: 129: non dev'omen seu cor encobrir / a quen...), but the verse is still deficient in sense. m'encobrir / dela (compare Qvando o seruo que é fugido for a casa dalguu por se encobrir de seu dono; Ferreira 1987: I, 290) frees up a needed syllable (see next note). We find dela in identical position (verse-initial, with enjambment, in the fifth verse of the first strophe) in Diego Moniz 2, v. 5.

$<$ sen>: the correction dela shows a syllable is lacking, focusing attention on que me faz perder, which is incomplete as it stands. The formula perder sen does not need an article: ja por ela lum' e sen perdi (CA 232.11); Osoir' Anes 3, v. 19 que non ei ja sen nen poder. On sen (from Germanic sinn) see García-Sabell Tormo (1991: 308-312).

7 References to texts in $C A, C E M$, and $C S M$ normally refer to poem number and verse(s), e.g. $C A 317.1$ The cantigas d'amigo are cited according to Cohen (2003), for example: Bonaval 1, v. 6. 
6 ca: $B$ has $Q u e$, but the conjunction is causal here (see note on Asme 2, v. 32).

pode $<\mathbf{n}>$ entender: both this verse and $\mathrm{v} .14$ end with entender. This repetition may be intentional, but there might be an error here. If we accept Michaëlis' emendation, he is referring back to his skill at hiding his love (vv. 3-5) so well that "they" cannot discover it. Still, is it possible that another expression has been displaced (see notes on Diego Moniz 1, v. 25, Osoir' Anes 4, v. 9, Osoir' Anes 5, v. 50 and Osoir' Anes 6, v. 14).

7 chus: this old form also appear in vv. 13 and 15. See Monteagudo (2008: 386).

$\mathbf{1 4}<\mathbf{c a}>$ : the verse lacks a syllable, and the clause needs an introductory conjunction to connect it with what goes before. Lang proposes an initial $<\mathrm{e}>$. (Michaëlis prints pode entender, supposing an unlikely hiatus).

16 afeito should be a single word. Though Michaëlis does not print it as such (or put it in the glossary), it is registered four times in CSM, once in CEM, and occurs once in the cantigas d'amigo (Meogo 2, v. 10).

17 trastornar: Michaëlis ( $C A$ s.v.) hazards "vaguear; vagabundear," citing only this passage. The verb occurs three times in CEM and Lapa glosses "revolver, atirar de baixo para cima." Compare CSM 255.57-60 E tant'andando / foi trastornando / e preguntando / que achou a via.

17-18 The sense is: "Whoever wants to trek across the world and turn it upside down (in search of the most beautiful woman) will easily find out that it is mine."

18 todo o mund', e: H. Monteagudo's adjustment of Michaëlis' correction of $B$ 's reading tedeo munde (personal communication, 2009). Compare CSM 55.78 cujos feitos todo o mund' apregoa, with hiatus: todo $\mid o$. (Miranda's todo $<l>o$ is impossible; it is only in the plural that we find todolos $<$ todoslos).

ferir: Michaëlis ( $C A$ s.v. ferir) is at a loss. (Nunes 1921 s.v. says "andar a bater às portas"). The meaning we need is "stomp (the earth), travel," a sense which does not occur elsewhere in the lyric, but does in prose: assy como se departe pelo foro da Cela e vay ferir ao rio do Mino (DVPM s.v. 3), where it means "go all the way to." Latin ferire could refer to beating the earth with the feet (OLD s.v. ferio 1a cites Tibullus 2.5.85: feriet pede rusticus uvas "the rustic will stomp the grapes with his foot"). If that is the right track, the evolution would be: "stomp the earth" $\rightarrow$ "walk" $\rightarrow$ "travel." 
19 festinho: the word, from Latin festinus ("quick, swift, fast, rapid" OLD s.v. 1), is rare and appears to be confined to verse. We find it in Pero da Ponte esto seja mui festinho (Panunzio 1992: 163). See also CSM s.v. festinno.

29 Ihela (B) combines a plural indirect object (see v. 26 lhes; v. 28 lhis) and a feminine singular direct object. A tonic object pronoun ela is possible (see, for example, CA 102.28 se non vir ela; Elvas 4, v. 5 se el perder), but more likely is lhela $<$ lhesla $(T M I L G$ registers llelo eleven times and llela seven).

32 en concelho means "in public," as in CEM 373.8 (Pero d'Armea): Vós andades dizend'en concelho / que sobre todas parescedes ben (see also CEM s.v. concelho). CSM (s.v. sair) glosses sair a concello as "tornar público," citing CSM 215.46: porque aquesto feito $\mid$ non sais $<s$ '> a concello.

avergonhei: paleographically, metrically and semantically this makes sense out of $B$ 's reading auey guey. We find $y$ for $r$ in Moniz 2, v. 35 enduray, and $u$ for $n$ is one of the most common errors in $B$. The reading could have been $\mathbf{a u e r g}^{\mathbf{0}} \tilde{\mathbf{n}} \mathbf{e y}$. Though rare in the lyric (it is not in the glossaries of CEM or CSM), avergonhar is used by this poet twice in the next cantiga (vv. 5 and 24), once reflexively, once transitively (it is employed reflexively in CA 59.30 quando vos non quiser avergonhar). By "identifying" his lady as the most beautiful woman in the world (vv. 9-12, 17-24) and thereby, according to his logic, naming her (v. 16), the speaker has taken revenge (v. 31) by publicly shaming her. (Michaëlis reads averiguei; Miranda, avoguei; but neither word fits and neither occurs in Galician-Portuguese lyric; Machado's auergüey is close: see VIII, 170 s.v averiguar).

\section{Airas Moniz d' Asme 2}

$a^{7} b^{6} a^{7} b^{6} a^{7} b^{6} a^{8} a^{8} b^{6}$ (x 5) ar edes / ei ades / er ia

Doblas (third pair incomplete). Rep. 62:1 unicum. See Correia (1995: 77-78). Meter and rhyme scheme are interwoven, with verses of $\mathrm{a}^{7}$ and $\mathrm{b}^{6}$ alternating through six verses, then a final section of $\mathrm{a}^{8} \mathrm{a}^{8} \mathrm{~b}^{6}$. This pattern evidently threw off a scribe higher up the stemma, who began to regularize the $\mathrm{a}^{7}$ verses, got through the first strophe (stretching to 8 syllables the third and fifth verses -he apparently took $m h a$ in v. 1 as bisyllabic) and the beginning of the second (vv. 10, 12), then gave up, leaving the pattern intact for the rest of the poem. Michaëlis saw the irregularity and left it. Tavani reports the scheme correctly. Metrical flaws would be especially damaging to a cantiga that uses subtle distinctions in verse length as an essential feature of strophic design. 
3 en gran: $B$ offers De mi que en tam gram vagar in what should be a 7-syllable verse, but that will not scan since the conflation que en is against phonology and metrics, especially in the early period (Nobiling 1907: 346-349; Cunha 1982: 129-161, 167). There is no need for tam and cutting it yields a metrical verse (see headnote).

5 The manuscript reads E cuidomeu auergonhar -a syllable long. eu is superfluous (see headnote).

7 oj' a: the manuscript's Oio can easily be corrected to oje (Miranda), since the article is not grammatically necessary. But a mha barva would correspond to la $m i$ barba in Hispanic epic (see below), so Michaëlis' emendation is preferable.

barva: the beard, symbolic of honor, abounds in the Cid. See especially $i$ bençio esta batalla por o ondro su barba (v. 1011) and Que avedes vos, conde, por retraer la mi barba? (v. 3283; see note on v. 274; Smith 1986: 172, 253, 278).

$10 B$ reads Caualeyroia uiltar. Lang would delete $i$, leaving aviltar. The verb does not appear elsewhere in the lyric; but forms (especially the participle) occur a dozen times in the Crónica Troiana, according to TMILG. One could divide the letters to read cavaleir', oj' aviltar, picking up oje in v. 7, but see headnote. (Machado and Miranda print $i$ aviltar, but $i$ cannot begin a clause -and the verse would not scan).

11 viltar- / <la>: meter and syntax are wanting in the transmitted text. Michaëlis supplied $\langle a\rangle$ because a direct object referring to the barva (vv. 7, 9, 12) is needed, and Miranda's nunca $<j a>$ fails to supply one. The technique of splitting words or inseparably linked syntax (here, an infinitive and its direct object) across a versebreak was a mark of skill-found from time to time in CSM. See, for example, CSM 7.44-46 Santa Maria tirar- / lle fez o fill'e criar- / lo mandou.

12 The manuscript has ia ela estar, producing a hypermetric verse (see headnote). Lang sees that $i a$ should be cut.

16 There is no break in the manuscript nor has Colocci left one of his cruces to indicate that something is missing (see on Osoir' Anes 7, v. 6). So this verse might belong here or might be v. 13 (as editors have assumed), since meter and rhyme are the same in both locations. But e desso que dizedes fits well as a transition to the rejection in v. 17. Compare Guilhade 5, v. 10 mais desso que mi dizedes, where an almost identical expression precedes a similar rebuff. 
26 e dade m' al i tries to make sense of $B$ 's Eda de mali, which Michaëlis reads as $e$ dade mal, where dar has no indirect object and the meaning is unclear. Lopes (2002: 23 ) proposes $E$ dade $m$ ' al ou, an inspired stab in the dark followed by a blunder: the sense is illogical (he means "Give me something and I'll go," not "Give me something or I'll go) and the verse as she prints it is hypometric. By al the speaker means an alternative to whatever he asked for. It might be inferred from vv. 41-42 (ca eu por tanto d'aver / nunca vos deterria) that he asked for a material gift, such as a cinta. If so, al could mean another gift, of lesser import but still symbolic. On the other hand, if he asked at first for sexual relations he is now ready to settle for a pointedly unspecified "something else," symbolic or otherwise. For uses of al in similar (erotic) contexts, compare fez mi tirar a corda da camisa / e dei lh' eu dela ben quanta m'el disse, / mais el demanda mh al (Guilhade 6, vv. 8-19); and O meu seria perdudo con migo / por sempr', amigas, se mi pediss'al (Guilhade 17. 8-9; see Cohen, forthcoming, Chapter 5). In that case the adverb $i$ might function here as it does in some cantigas d'escarnho e maldizer: a deictic gesturing towards female sexuality. For an obvious example, see CEM 250.26 ca ja en min meteu do seu $i$ ben (a woman is speaking).

32 ca: Michaëlis' correction of que (see, for example, $B 96$ / $A$ 9, v. 13: ca $A$ : q’ $B$ ).

33 u ren non adubades: "Where (or since) you won't get anything." The verb adubar (see García-Sabell Tormo 1991: 21-23) can be explicitly sexual, as in CEM 245.3 and CSM 105.57-58 que nunca el pode ren adubar / con a donzela. Compare the girl's rebuke in Esquio 4, v. 1 Que adubastes, amigo, alá en Lug'u andastes -near the lower limit of the register in the cantigas d'amigo. The nature of the man's requests is reflected in the woman's refusal.

36 ar uenhades is the reading of $B$ (Miranda prints ar $i$ venhades without any basis).

ar: this adverb (or particle) so far has no convincing etymology (Nunes 1989: 350-351 takes re-from Cornu; Michaëlis CA s.v. ar derives it from ad re-). But it may plausibly be traced to Latin ad (as a verbal prefix), which could become ar in front of labials, a sound change for which there is evidence in archaic inscriptions (Weiss 2009: 475-476): ARVERSVs (OLD s.v. aduersus ${ }^{4}$ ); ARFVISE (= adfuisse, OLD s.v. adsum); APVR FINEM (OLD s.v. apud). Thus, aduenit (for example) would have become *aruenit and this would be the immediate source of ar ven. Once ar had been reanalyzed as an adverb, its use would have spread to other verbs and then to other constructions. But its origin as a prefix explains why it nearly always precedes a verb (sometimes an implied verb, or an adverb or adverbs just before a verb; it is 
rarely found in any other construction). In these twelve texts ar occurs seven times, always before a verb: Asme 2, vv. 2 (ar pensedes) and 36 (ar venhades); Diego Moniz 1, vv. 19 (ar mataria) and 22 (ar matava); Osoir' Anes 2, v. 32 (ar querrei), 8, vv. 5 (ar poderedes) and 6 (ar quiserdes). The oldest meaning of Latin aduenire is "to arrive" (OLD s.v. aduenio 1) and by extension "to come back," exactly what ar vĩir usually means and what it means here.

44 prazer is Michaëlis' correction of plazer, a form which occurs in the sixteenth century Italian apographs, $B$ and $V$, but not in the Cancioneiro da Ajuda (siglum $A$ ) or in the Toledano manuscript of the Cantigas de Santa Maria (siglum To), both thirteenth century codices (see $C A$ s.v. plazer). From this we can infer that it is a late form which has displaced an original prazer. We also find plazeria in Osoir' Anes 2, v. 1 .

45 Probably not the end of the poem. Both the scheme of cobras doblas and the dialog pattern suggest that one strophe is missing. (An accident of transmission, or silencing woman's voice?).

\section{Diego Moniz 1}

$a^{7} a^{7} x^{7} b^{7} b^{7} c^{7} c^{7} d^{7} d^{7} \quad(x 4) \quad$ ia or ava er / ava er ia or

A palavra perduda (x) alternates in rhyme from or to $e r$, the other member of the pair appearing as the d-rhyme. The a-rhyme and b-rhyme alternate: I > III, II > IV. Rep. 51:1 unicum. See Gonçalves (1993); Billy (2003: 56-57).

6-9 Presumably, the subject of fazia (v. 7) is the lady, since seu (v. 9) should refer to the subject of the clause: "And I didn't thank God for the favor she did me just by letting me see her beauty." Alternatively (with theological, but no grammatical compunctions), Deus may be the subject of fazia: "the favor He did me."

10 sandez: at CSM 94. 55 this form is found in rhyme. The normal form is sandeçe, sandeç' before a vowel.

13 que stands in for quando (v. 11) the second time round. Compare Queimado 3 (vv. 4-5): quand' aqui chegar / e que lh' eu falar non quiser (see Nunes 1926-1928: I, 396; Huber 1986: 301; par. 482, note).

queria: my correction of q'rriã (B), which previous editors have printed as querria. But here the verb must refer to the past -which the conditional cannot do (in the 
next verse the viewpoint has shifted, and the conditional pagaria has the present as point of reference). Confusion between queria and querria is common in $B$. See, for example, $A 200$ / B 351, v. 4 queria $A$ : queiria $B$ (=querria). (See Cohen 2003: 615, note 1.)

15 dava: the imperfect dava may be modal here, equivalent to a conditional: "Who could give me this (now)?" Compare the modal force of cobrava in v. 28 (see note). But entrava in v. 16 refers to the past.

16 que non m' entrava: queno nõ entraua, the reading of $B$, neither makes sense nor scans. Michaëlis' emends to que non m'entrava, without translation or gloss. The change is simple paleographically, but the sense needs clarification. Only one of the various meanings of the verb appears to be relevant: "to take possession of," in a legal sense: o Maestre e a Ordin d'avis.per ssa outoridade possam entrar.e filhar.e possoyre auer pera todo sempre.os sobredictos herdamentos (DVPM: 178, s.v. 3; see Ferreira 1987: II, 122-123, where the phrase is entrar en). The sense would be: “...this ben, that didn't take possession of me," or “didn't grip me." The impersonal use of entrar, meaning "penetrate (the heart, the will)," as in CSM 234.20 and 312.45) probably cannot be invoked here.

18 E vivess' a tal sabor: Eu messental sabor, $B$ 's reading, offers an easy correction at the beginning of the verse: $m$ is often found for $i u$ (or $u i$ ), so by combining the $u$ of $E u$ with iu (for $m$ ) we get uiuessen: vivess' en. Michaëlis, however, prints $E$ ouvess' eu tal sabor, probably because sabor is usually found with aver (a few times with prender, dar, tomar, perder), while viver en sabor seems not to be documented (viver sen sabor is common; see Osoir' Anes 1, vv. 9-10). But we find a sabor, for example, in Cangas 2 (vv. 7-9 e non vi / meu amigo con que quisera falar / a mui gran sabor nas ribeiras do mar) and the expression estar a sabor appears in Lourenço 3 (v. 20 a que gran sabor estava), so the construction here would be viver a sabor.

17-18 non ouvess'... /... vivess': although both verbs are independent optatives, non ouvess' is here equivalent to a protasis, while vivess' functions as an apodosis: "Let me have no better! And let me be that happy!" is tantamount to "If I had no better, I would be so happy!"

20-21 um cor que ei de folia / mui comprid<0>, e d' amor: "My heart full of folly and of love." folia (see García-Sabell Tormo 1991: 147-148) can refer to sexual desire (as here) or activities. See CSM 115. 62 (where there can be no doubt) and Guilhade 6, v. 15 mais el demanda mi $\mid$ outra folia (where we can only guess). 
22 per poucas, meaning "almost, nearly," is found only here in the secular lyric, but six times in CSM (according to TMILG).

25 sabia has already been used in rhyme in v. 1 (see notes on Asme 1, v. 6, Osoir' Anes 5, v. 50 and Osoir' Anes 6, v. 14).

27 por dela mais ben aver: see, for example, Johan Airas 7, vv. 1-2 O meu amigo non pod'aver ben / de mi (vv. 1-2), where coyness makes clear that aver ben de can mean "to receive sexual favors from (a woman)." Compare Baveca 13, Johan Airas 7 and 27, Servando 12 (see Cohen, forthcoming, Chapter 2).

28 se eu ... cobrava: "If I could get back..." The imperfect indicative must be modal here, corresponding to an imperfect subjunctive in a contrary-to-fact condition, as if we had se eu cobrasse. This is shown by the conditional in the apodosis: saber lh'ia (v. 30). In this context nunca means "ever." Michaëlis translates vv. 28-29: "Gewönne ich je die Lust zurück, in der ich früher lebte..." ("If I could ever win back the happiness in which I lived before..."). Huber (1986: 311, par. 495) gives one example of such a usage, within a past narrative -not a close parallel. See v. 15. (Rhyme-driven syntax?)

32-33 An elegant -and certain- emendation. B reads: $Q$ ' ela nõ podia uiuer / Quãdalhur moraua. The supplement $<$ sen $>$ ela moves podia to rhyme-position at the end of v. 32, so that v. 33 begins with viver. At one stroke Nobiling fixes the meter, rhyme, syntax and sense of two verses. (Ferreiro Fernández / Martínez Pereiro 1996: 36 print que <eu> viver non podia / quando ela alhur morava.).

alhur morava: this expression can mean simply "to live somewhere else," but it can also mean "to love another" or "to have another lover" (Indini 1979: 110; compare Osoir Anes 2, vv. 15-16 quando s' el for / alhur servir outra senhor). If that is the sense here, it would thicken the plot. On alhur, see García-Sabell Tormo (1991: 38-40).

\section{Diego Moniz 2}

$a^{13} a^{13^{\prime}} a^{13} b^{10} b^{10} \quad(x 1.4) \quad$ ia er / ia ...

Unissonans. Rep. 16:18. Maybe aaaBB. The strophic form was analyzed by Michaëlis, duly registered by Tavani (Rep. 16: 8), and repeated by Gonçalves (1993), but ignored by Miranda. In $B$ our vv. 1, 2 and 7 are copied as whole verses, but the scribe had no room for this procedure (the last three letters of $v$. 1 had to be written above the first part of the word). 
1 como a mi: comomami, the reading of $B$, is given by Michaëlis as como m'a mi but this produces a hypermetric verse and the correction is simple.

prazeria: see note on Asme 2, v. 44.

7 This verse ends the folio and following it there are two blank folios, nos. 12 and 13 (blank except for Colocci's invaluable calculations on 13v; see Ferrari 1979: 41-54).

\section{Osoir' Anes 1}

$a^{8} b^{8} a^{8} b^{8} c^{8} c^{8} d^{8} d^{8} \quad(x 4) \quad$ or ou ei ar / er ęr i al

Doblas. Rep. 107:4. See Canettieri and Pulsoni (2003: 139-142). The dobre in vv. 1 and 3 of strophes I-II (amor v. 1, desamor v. 3; sabor vv. 9 and 11) is thereafter dropped, though poder in vv. 19 and 25 seems an echo of the dobre, occurring in each of the two positions in the strophe which are occupied by the dobre in I-II. In addition, amar and mal both recur in rhyme in what seems like a deliberate pattern (amar I.7 > II.8; mal III.7 > IV.8).

1-6 Being unable to leave the beloved, going back after leaving, being forced back - all are found in other cantigas d'amor, for example (nearby in $B$ ): $C A 338.19$ nen ei poder de vus fogir: 342.5-6 E faz mi-a mercee vĩir / d'Amor, com'ome preso ven; 352.14 Non lhi posso fugir; 355 (a request to be taken back); 357.31-32 Ca non ei eu a vos fugir / nen outra senhor filharei. Returning against one's will to a lover is a topos of ancient Greek and Roman poetry. See Tibullus (2.6.13-14): Iuravi quotiens rediturum ad limina numquam! / Cum bene iuravi, pes tamen ipsa redit ("How many times I swore I'd never go back to her door! But after I'd sworn up and down, my feet went back by themselves").

2 quen<n>: Michaëlis' correction is necessary. There is a syntactic rule that requires quen (for human beings and their like) whenever the antecedent is absorbed by the relative pronoun, which thus functions in two clauses. Here quen is the direct object of amar and the subject of amou: "And [Love] made me love someone who never loved." (Miranda, who prints que, does not print quen even when it is required by grammar and present in the manuscript; see note on Osoir' Anes 5, v. 22.) .

4 que: here $B$ has quen but what is needed is que functioning either as a causal conjunction or as a causal relative: "since he sent me back to such a lady." 
4, 6 The construction with tornar is causative in v. 4, meaning "to make (somebody, something) go back to/from (somewhere, something, somebody)" and apparently reflexive in v. 6. For the causative, see CA 231.19-21 se me Deus ajudar / e me cedo quiser tornar / u eu ben vi, ben veerei; Johan Airas 27, v. 13 ren de morte non o tornará. (Lorenzo 1977: II, 1263 s.v. tornar glosses this use as "llevar al lugar donde se estuvo"). For the reflexive: CEM 135.18 quando m' a ela tornei; CA 64. 1-2 Quisera-m 'ir; tal conselho prendi; / e fui, coitad', e tornei-me por én! Hence, Love made the speaker go back (v. 4); he went back (v. 6). Although causative force is inherent in the reflexive use (the difference being that between "I made myself go back" and "I went back"), reflexive pronouns are not normally tonic (Nobiling 1907: 343-345); but in v. 6 meter shows the object pronoun mi has syllabic integrity (stands unelided), and its tonicity is emphatic. So the construction is parallel, if not identical, to that of v. 4 .

4, 6 mí: for metrical and grammatical reasons (see previous note), $m i ́$ is not elided in vv. 4 and 6 and must be a tonic object pronoun, like min in vv. 1 and 16. (Ferreiro Fernández / Martínez Pereiro 1996: 156 print mi a tal in both places, but this is equivalent to $m h$ a tal. To mark the form as tonic they would print $m i$.).

12 sou < SŬŬM ( = seu) is an archaic form (Nunes 1989: 243-244; Williams 1938: 39; par. 38.10). Compare CEM 314.6, 410.10; CSM 23.6, 406.4, and see Monteagudo (2008: 384-385).

15 viver ei (not viverei) is needed on strictly syntactic grounds, so that ei can also govern morrer in the next verse.

18 mego: an archaic form, cited only here by TMILG. Its reconstructed brethren comego and cõmego occur in three compositons, including Osoir' Anes 4 (v. 4). See Monteagudo (2008: 384-387).

vid' over: Michaëlis prints $o u<v>e r$, but ouer is the regular form in the Foro de Castelo Rodrigo (Cintra 1984: 167, 467). On this and related forms, see Monteagudo (2008: 186-201, 370-377). If correct (I find no parallel), the expression quen mego vid'over would mean something like "whoever has spent time with me."

28 Miranda prints se m'en Deus i poder non der, producing yet another $i$ not present in the manuscript (see note on Asme 2, v. 36).

30 dou (Williams 1938: 230; Nunes 1989: 322) is a variant form of the third person singular perfect indicative of $d a r$ formed by analogy with regular first conjugation 
perfects as if from * DAVIT. It occurs in rhyme at CEM. 472.18. (Michaëlis mistakenly translates it as first person present, then corrects herself in the glossary, $C A$ s.v. dar). See Monteagudo (2008: 385-386).

32 erg': see Monteagudo (2008: 381-384).

<gran> supplies a syllable and some point, both of which are lacking in the transmitted text. Compare, in Dinis: Senhor, creede / que a vossa fermosura / mi faz gram mal sem mesura, / porem de mi vos doede (Lang 1894: 99; analyzed as a paradigm of the male wooing discourse by Cohen 1987: 1-3).

\section{Osoir Anes 2}

$a^{8} b^{8} b^{8} a^{8} c^{8} c^{8} d^{8} d^{8} \quad(x 4) \quad$ I-II: ir ei i or III: á ar en er IV: ar ęr á eu

Rhyme sounds interweave in III-IV, instead of doblas: b-rhyme of III becomes a-rhyme of IV, a-rhyme becomes c-rhyme. Rep. 168: 6. See Billy (2003: 43); Canettieri and Pulsoni (2003: 139-146).

The man speaks vv. 1-13. First (vv. 1-5) he summarizes the situation; then (vv. 6-13) he imagines what he will say to his lady before he leaves. The rest of the poem (vv. 14-32), in female voice, represents what (in the scene he is imagining) he will tell the woman that she will say after he is gone. The woman's speech thus occupies the center of this unusually complicated dramatic and narrative structure. Bertolucci Pizzorusso (1993: 113-114) discusses the "other woman." The other, male or female, is hardly a medieval invention. In ancient Roman poetry, looking for, finding, or threatening to find another beloved is often (but not always) a topos of the renuntiatio amoris, and is used to escape from the beloved or to make her (or him) jealous ${ }^{8}$. (On outra and outro in the cantigas d'amigo, see Cohen, forthcoming, Chapter 6.).

8 See, for example, Plautus, Epidicus 135 illam amabam olim: nunciam alia cura impendet pectori; Lucretius 4.1173 nempe aliae quoque sunt; nempe hac sine viximus ante; Virgil, Eclogues 2.73 invenies alium, si te hic fastidit, Alexin; Horace, Epodes 15.23-24 heu heu translatos alio maerebis amores: / ast ego vicissim risero; Tibullus 1.5.39ff saepe aliam tenui...; Tibullus 1.9.79-80 tum flebis, cum me vinctum puer alter habebit / et geret in regno regna superba tuo; Propertius 2.5.5-8 inveniam tamen e multis fallacibus unam / quae fieri nostro carmine nota velit, / nec mihi tam duris insultet moribus, et te / vellicet: heu sero flebis amata diu; Propertius 2.22.37-40 altera me cupidis teneat foveatque lacertis, / altera si quando non sinit esse locum; / aut si forte irata meo sit facta ministro, / ut sciat esse aliam, quae velit esse mea; Propertius 4.8.27ff; Ovid, Amores 2.4, 2.10; Ovid, Remedia Amoris 441-445, 450-451, 461-462. Many female rivals inhabit Ovid's Heroides. 
2 temp' ei: the normal expression would be temp'á, and Michaëlis is understandably puzzled by this unparalleled variation ( $C A$ s.v. tempo), guaranteed by the rhyme.

8 guaanhei: bisyllabic.

19 mingua: compare mengua in v. 17; see Monteagudo (2008: 379-381).

20 rancurado: Michaëlis translates "zornig" ("angry") and glosses "ressentido" (CA s.v. rancurado). The word is cited only here by TMILG. See the notes on Osoir' Anes 5, v. 26 and 6, v. 11.

salrrá: solhira (B) looks like salira, the normal spelling of salrrá in $B$, so Michaëlis' salrá has paleography and grammar in its favor. The only parallel I find for sair de alguen comes in a cantiga d' escarnho of Pero d' Ambroa: de sair dela sol non é pensado, where dela refers to a woman, metaphorically an ermida velha (Alvar 1986: 80-81). In Froiaz 4, vv. 13-14 we find the same form in rhyme: $\langle E>$ ja meu amigo nunca salrrá / de meu mandado nen de meu poder; but the construction is different. (Miranda prints sol irá, which does not scan and makes dubious sense.)

23 mho: $B$ has $m e u$. Cotarelo y Valledor's me $o$ is what the reading probably had been further up the stemma. See $A 16 / B 109$, v. 20: mio $A$ : meu $B$ (the correct reading is $m i-o$ ); and compare the apparatus to Berdia 4, v. 8: mi-o Nunes : me o $B$ : me $V$, where the reading is confirmed by the identical phrase in v. 6 (both $B$ and $V$ have $m h o$ ). Earlier in the transmission readings like me $o$ and $m i o$ were converted to $m h o$, and some cases escaped the conversion. (Miranda prints meu, which he wants to mean "what's mine," but the article would be required for such a construction.).

receber: the first and third person singular of the future subjunctive of weak verbs ends in close $e r$ and so can rhyme (unlike the corresponding strong forms, which end in open err; see note on v. 27) with present infinitives in er. This is the only place in these twelve texts where such a rhyme is used. These rhymes are not uncommon in CEM and the cantigas d'amor, but are rare in the cantigas d'amigo, where there are only three examples: Galisteu Fernandiz 3, v. 5 viver; Folhente 1, v. 13 viver; and Elvas 4, v. 5 perder (Cohen 2003: 492, 270, 348; in the first two cases the cruces and the notes "explaining" them should be deleted; in Pardal 4, v. 13 the cruces should remain, but in note 1 the first of the two grounds given is wrong and should be struck).

24 cõmigo se pode perder: perderse con alguen, meaning "to be all washed up with (someone)" or "no longer to be a friend/lover of (someone)," is commonly 
used in the cantigas d'amigo to refer to the end of a relationship between girl and boy (Cohen 1996: 42, note 25). In a cantiga d'escarnho where this expression is parodied, Pero d'Ambroa drives home its potential reciprocity (Alvar 1986: 84-86): que se non perdess' el poren comigo / nen eu con el (3-4); que me non aja con el de perder / e el comigo (6-7); e perdeu s'el comigo / e eu com el (10-11); e per aquesto perder-s' á comigo / e eu com el (17-18). Here it refers to a relationship between vezias (from the same town) who may "fall out" with each other over the man (the speaker in vv. 1-13).

25 e: $B$ has $o s m o$, Michaëlis prints osm' $e$. This is preferable to $o\langle u>$ since the verbs which are being coordinated, assanhar and maldisser, represent sequential actions.

assanhar: compare Talaveira 8, v. 6 se m'assanhar; Servando 2, v. 4 se me lh' eu ant' assanhar, v. 16 mais, se m'eu for assanhando. The woman's use of this verb is striking because (in the lyric) finite forms of assanharse are found almost exclusively in the cantigas d'amigo, where they play an important role (Cohen 1996: 5-27, 48-50).

27 a tolher: the manuscript has atolh (= atolher; compare the abbreviated form toll' in the "Toledano" (To), for example, Afonso X, o Sabio 2003: folio 20v, col. b, line 15). But this was misread by Molteni and printed by Michaëlis as acolher ("receive, take in"). Here tolher means "to steal (someone's beloved)," as in Sevilha 8 (vv. 2526 outras donas an / falad'en como volo tolherán) and Bolseiro 7 (v. 17 pois que mho vós tolhestes) and is roughly parallel in meaning to sussacar (v. 28), though a sequence of actions seems to be intended: "If my neighbor steals him from me (se mho... a tolher oer) and seduces him (e mho sussacar)..." (Miranda wants acolher at the end of the verse, but the future subjunctive acolher, from a weak verb, ends in close er, while disser, from a strong verb, ends in open ęr. The poets never rhyme these two classes. See Huber 1986: 242, par. 400; Ferreiro 1999: I, 312-314).

28 e: Michaëlis prints ou for B's $o$; but $e$, an even easier correction, co-ordinates tolher and sussacar (see note on v. 27).

sussacar: this verb, meaning "entice, seduce," appears as a legal term in the Foro de Castelo Rodrigo (Tod omne ou moller que sosacar filla allena pora outro; Cintra 1984: 50) and the Foro Real (Jews must not entice Christians away from their faith; Ferreira 1987: I, 263; II, 281 s.v. susacar). See also CSM s.v. sossacar (the devil entices).

28-29 vezia: only here in Galician-Portuguese love lyric (but see CEM s.v. vezinho and CSM s.v. vezinna, vezinno). maō vezĩo (B) in v. 29 cannot stand (unless grammatically 
indifferent as to gender), since it must refer to the vezia of v. 28: "If a vezĩa ..., she will be a maa vezia." (mao vezio cannot refer to the man: he does not imagine the woman calling him names; he imagines two women fighting over him.).

30 vol' a sentir á: Michaëlis takes $B$ 's uola to be an error for volo (la would have no antecedent; compare $m h a$ in $B$ in vv. 29, 28) and prints vo-lo sentirá, the sense being: "But, you know ( $v o-)$, she won't have to feel it (-lo = my anger)." We get the same or better sense (without changing a letter of the manuscript) by construing aver a sentir (compare v. $7<a>$ veredes a sentir). Either way, the other woman (it is hoped) will be neighborly and not try to steal the man. This presupposes a female solidarity rule, to which the woman claims that she adheres (v. 31).

31-32 These verses are much like the finda of Johan Airas 1 (vv. 19-20): Cofonda Deus a que filhar o meu / amig', e min, se eu filhar o seu. Here, o seu presumably refers to the same man, once he has become the the other woman's boyfriend. See Johan Airas 43, especially vv. 19-20 (fiiinda), where the girl imagines she has won back her lost boyfriend from another girl: $\langle E>$ enton veredes molher andar / pos min chorand', $e$ non lho querrei eu dar. (On both texts see Cohen, forthcoming, Chapter 6).

\section{Osoir' Anes 3}

$a^{8} b^{8} b^{8} a^{8} C^{8} C^{8} \quad(x 2) \quad$ ei ar ez / er á ez

Variation in first verse of refrain. Rep. 160: 367. (On the new lady, see Bertolucci Pizzorusso 1993: 112-113).

2 afan: see García-Sabell Tormo (1991: 24-29).

$\mathbf{8}<$ mal $>$ servid': a syllable is missing, and the context requires that the first two verses mean: "Any lady who loves well will never be badly served thereby (én)." The reading of $B$ says the opposite. An example of such a woman -who benefited from being well served- is provided in vv. 9-10. (For a woman's take on service, see Guilhade 17.).

\section{Osoir' Anes 4}

$\begin{array}{lll}\text { I } & a^{8} b^{8} a^{8} b^{8} c^{8} c^{8} b^{8} & \text { I: on ar or } \\ \text { II-III } & a^{8} b^{8} b^{8} a^{8} c^{8} c^{8} a^{8} & \text { II: ar on eus III: ar on or }\end{array}$ 
The a-rhyme and b-rhyme switch places from I to II. Rep. 101:55, 161.266. See Billy (2003: 38). The rhyme scheme in the first strophe $a b a b$ might seem off (the other two strophes begin $a b b a$ ), but any temptation to transpose vv. 3 and 4 runs into problems, since it is difficult to see how the adverb $i$ in v. 3 could precede its referent (prison v. 4). Once again, see Bertolucci Pizzorusso (1993: 112-113) on the change in appetite.

4 ed ir: Michaëlis' version of v. 4 scans a syllable short (de | ir supposes an impossible hiatus) and the construction que me non podesse forçar /.../ d'ir comego is confusing, since the speaker cannot be forced to go with himself. However, ir is a sensible reading of the last two letters of B's edit. The subject of podesse... ir would have to be meu coraçon (v. 1), but for there to be a syntactic parallelism with podesse forçar (v. 2) we need a coordinating conjunction, and that is precisely where $B$ gives us $e d$, an archaic form of Lat. et with the voicing of intervocalic - $t$-. See Monteagudo (2008: 386-387). The speaker had not thought his heart (1) could force him, and (2) go back there with him: cuidei ... que me non podesse forçar ... ed ir comego.... On ed, compare Solaz 2, v. 4 ed oi (Cohen 2003: 287-288; see Cohen \& Corriente 2002: 26-27).

5 nov' amor: the idea and the expression occur in Latin, for example in Cicero (Tusculanae Disputationes, 4.75): etiam novo quidam amore veterem amorem tamquam clavo clavum eiciendum putant ("Some even think that an old love must be driven out by a new love just as a nail is driven out by a nail"); and Ovid (Remedia Amoris, 462): successore novo vincitur omnis amor ("Every love is conquered by a new love that succeeds it"). These and other passages of Roman literature may be the ultimate source of the topos found in Occitan poetry.

9 enton is used again in rhyme in v. 17 (hence, II.2 > III.3). See note on See Diego Moniz 1, v. 25.

10 cuidei: Michaëlis' correction is required by the sequence of tenses: cuidei...que non / podesse, which exactly parallels the construction in the first strophe (see note on v. 4).

11 cobrar: compare CSM Prologue B, vv. 24-26: querrei-me leixar de trobar des $i /$ por outra dona, e cuid' a cobrar / per esta quant' enas outras perdi.

16 cabelos: the only occurrence of the word in the cantigas d'amor. But cabelos appear in the cantigas d'amigo in Soarez Coelho 1, Porto Carreiro 1, Zorro 5, Meogo 5 and Meogo 6, always with erotic connotations. 


\section{Osoir' Anes 5}

$a^{7} b^{7} a^{7} b^{7} a^{7} b^{7} b^{3} b^{7} a^{7} \quad(x 6)$

I-II: ades ei III-IV ado ar V-VI ia er

Doblas. Rep. 67:1 unicum. The last two verses of each strophe stand on one line in $B$.

3 gãades: Michaëlis adds a til here and in Osoir' Anes 6, v. 12 tẽer and Osoir'Anes 7, v. 5 dẽostar. Wherever we can compare $B$ with $A$ the til is regularly present in $A$ where it is lacking in $B$. See, for example, the text and apparatus of $C A 20.4$ tẽen $A$ : tem $B ; 26.24$ mẽor $A$ : meor $B ; 46.15$ tẽedes $A$ : teedes $B$. Missing tils in $B$ and $V$ should not be considered evidence of denasalization in the thirteenth century.

7-8 dereit' ei: literally, "I am in the right," Michaëlis translates: "Recht wäre es" ("It would be right"), but that rendering stems from her construal of the next clause, and dereit' ei can hardly govern the indicative segurades (cf. Huber 1986: 294, par. 471; Lorenzo 1977: II, 1178 cites this passage with seguredes). He is right to suffer, because...

8 que: we could print $c a$ (see Asme 1, v. 32). The clause provides a reason for the preceding statement (see note on v. 7).

segurades: Michaëlis emends $B$ 's segudides to segurades and translates "schutztet gegen" "protect from" (see CA s.v. segurar). The construction with de (da ren v. 8; daquela v. 9; de vós v. 10) supports the emendation, but not the sense she gives the word. The only other time segurar occurs in the lyric it is construed differently (CSM 28.135), but in prose it can mean what Michaëlis wants, and in the same construction (see DVPM: 355 and Lorenzo 1977: II, 1178). Still, "It's right that you protect me from you" makes no sense here. However, segurar can also mean "keep something away from someone" (Ferreira 1987: II, 269, s.v. segurar). "Because you keep me away from you" is what the context calls for. She fends him off.

segudides $B$ : it should at least be noted that $B$ 's reading looks like segudades, from segudar ( < *SĚCŪTĀRE $\leftarrow$ SĚCūTU-; REW 7778), meaning "to pursue" an enemy (Todos los parentes que inimigo segudaren, seguden parentes d'ambas partes; Cintra 1984: 60). But it is hard to see how segudades would fit the passage.

10 certas, found only here in Galician-Portuguese lyric, means "certainly, of course.” See García-Sabell Tormo (1991: 94). 
11 muit': my emendation of Ouir, the unintelligible reading of $B$. Both Nobiling and Lang think that syntax requires que: "And, surely, you should know that (sabhades que) I didn't desire a favor (=amor)." But the sense is contradicted by the context: that is what he wanted. Further, the conjunction is not obligatory in the construction they assume (see, for example, Fernan Velho 1, vv. 7-8 Oi dizer por me fazer pesar / amades vós outra). And sabhades may be parenthetical here ("Certainly, you know..."), requiring no conjunction, since then desejei stands in an independent clause. In either case, the only solution I see is that Ouir is a corruption of muit ( $r$ and $t$ are quite similar in thirteenth century gothic miniscule; see, for example, To, f. 71r, col. b Muit; the reverse in edit for edir in Osoir' Anes 4. v. 4). If this is correct, muit' amor non desejei would mean: "I wasn't asking for a big (erotic) favor." The magnitude of the favor does seem to be at issue: he says in vv. 12-13 that if she thinks that is what he desired, she is certainly (ben leu) doing him an injustice -implying that to ask so big a favor would be unbefitting. For the expression desejar amor, see CA.374.10 porque desejo voss' amor; CA 388.25 en deseja-lo voss' amor; and for the thought, albeit inverted (the speaker admits he is guilty of having desired muito ben from his lady): CA 17.1-3 Non me poss' eu, senhor, salvar / que muito ben non desejei / aver de vos. muit' amor is not found elsewhere in the lyric, but according to TMILG it appears (with various spellings) roughly ten times, beginning in 1283 .

13 ben leu: here, "certainly." This Provençal expression is found in GalicianPortuguese only in verse (see García-Sabell Tormo 1991: 203-205; Monteagudo, 2008: 377-378).

20 pesar: penssar is the reading of $B$ and most editors have been content to print pensar, but I find no parallel either for este pensar or for aver pensar. Cotarelo Valledor alone prints pesar (this is his one contribution to the text). aver pesar (CEM 12.1 muit'ouve gran pesar) and este pesar are well documented (the latter cited six times from the lirica profana in TMILG). In addition, este pesar fits into the wordplay with pesa in the next verse. For the insertion of an etymological $n$ where it does not belong, compare Diego Moniz 2, v. 3 monstraria.

22 quen: an absorbed relative. See note on Osoir'Anes 1, v. 2 (Miranda fails to recognize a common manuscript abbreviation and prints que).

24 lhe: plural, referring to "them" (vv. 19, 22, 26; see v. 31). Similarly lhi, v. 31.

26 rancurar seems to be cited only here by TMILG, but see Corominas (IV, 767 s.v. rancio). In Medieval Latin rancorare can mean "to institute [legal] proceedings" 
(Niermeyer). Michaëlis translates "schmollen" "sulk" ("ter ressentimento" in her glossary, $C A$ s.v. rancurar). Is he grumbling to himself about his lady or complaining about his companions (whose intrusive questions are the subject of vv. 19-24)?

27 Michaëlis translates vv. 25-27: "Und muss mich vor ihnen hüten, und schmollen, und so thun, als schenkte ich ihnen Aufmerksamkeit" ("I must be on my guard against them, and sulk, and act as though I were paying attention to them"). Lang (1908: 308), saying the translation of v. 27 suits neither the words nor the context, renders instead: "Und (muss) gleichsam immer bedacht (behutsam) sein" - "And (I must) constantly be careful (cautious)."

40 desta means desta vez (see CEM 46.8 Mais desta seerei eu escarmentado and the note on aquela in Vallín 1995: 232).

se desta posso viver: Michaëlis (1904: I, 653) translates "Wenn ich dieses Mal davonkomme" ("If I survived this time").

49 atal cannot be separated here, as in Michaëlis (there is no preposition here).

50 poderia: the repetition of this form, used in rhyme two verses above, may indicate a corruption (it would be a flaw in a song whose strophic form is meant to impress). Perhaps guariria or viveria would suit the sense of the passage (vv. 46-50), which seems to be: "God would not take me (if I died-since I have sinned), and (if I didn't die) I would not survive" -a logic not without its humor. See Asme 1, vv. 6 and 14, Diego Moniz 1, vv. 1 and 25, Osoir' Anes 4, vv. 9 and 17, and Osoir' Anes 6. vv. 10 and 14 for other words repeated in rhyme (considered a grave fault in Provençal poetics, except where symmetrical and regular).

51-54 When he has gone to bed his visions of the beloved ought to be sufficient. This need not be courtly or neo-platonic.

52 entender: the reading of $B$, e entender, could be forced to scan with aphaeresis (absorption): $e$ 'ntender. But if we take v. 51 as a subordinate clause, $e$ would be odd here at the beginning of the main clause. Without the conjunction we could render: "Once I lie down to sleep, thinking about her beauty should be enough." But although entender has many meanings (think, perceive, see, feel, judge), entender en specifically means "to be a lover of" (for example, Pereiro 1992: 72 sa coirmãa, en que entendia). 


\section{Osoir' Anes 6}

$a^{10^{\prime}} b^{10} a^{10} b^{10} b^{10} b^{10} a^{10} b^{10}(x 2) \quad$ ura er

Unissonans (so far). Rep. 87:1 unicum.

8 vós: the tonic object pronoun is proleptic, anticipating vos in perder vos ei in v. 9.

9-10 I take que as causal $(=c a)$ and construe tan muito .../ de mal. This sense is: "because so great a pain as I must suffer at your hands endures." The speaker will lose the lady because the lasting rancor will oblige him to renounce her. This serves as foil for the next verse: the bitterness will last, but he will not leave her in anger.

11 aver rancura: $B$ reads aver senõ rãcura but senõ has no place here: it overextends the meter by two syllables and reverses the sense, which is: "I can't get angry at you."

rancura: Michaëlis ( $C A$ s.v.), citing only this passage, offers the glosses "ira, raiva, aversão." Mettmann, based on the examples in CSM, says "pena, tristeza, queixume." The word (with a variant rencura) is common in medieval Iberian Latin and Romance with the meaning "complaint, legal action"(see Niermeyer s.v. rancor 4, and Corominas, cited in the note on Osoir' Anes 5, v. 26, above). The expression aver rancura was widely employed, in both an everyday sense (CSM 303.26 ouve dela gran rancura; 315.31 ouv'én tan gran rancura) and a technical one (often in the Foro do Castelo Rodrigo in formulas: Qvi $r a<n>$ cura ouere de outro; Cintra 1984: 33). Both uses occur in the $\mathrm{Cid}$, where the technical sense appears at key moments: dar le $<e>$ des derecho | ca rencura ha de vos (v. 2992; Smith 1986: 243). But the legal use comes from the quotidian, and Michaëlis is right: he cannot get angry at her, that is, he cannot renounce her and so "lose her" (vv. 8-10).

14 sofrer: the same word appears in rhyme in v. 10 (see note on Osoir' Anes 5, v. 50), motivating Nobiling's suggestion prender (which Machado thinks overly fine). aver is also possible (for instance, Airas Nunes 4, v. 16 " d'amores ei mal.").

\section{Osoir' Anes 7}

$a^{10} b^{10} a^{10} b^{10} b^{10} a^{10} \ldots \quad$ or ar

one (incomplete) strophe 
4-5 The speaker's fear of a woman who "neither kills nor captures, neither insults nor responds roughly..." may have been foil for an upcoming paradox.

6 Angelo Colocci placed a cross in the right hand margin next to this verse, indicating that something was missing.

\section{Osoir' Anes 8}

$a^{8} b^{8} b^{8} a^{8} c^{8} c^{8} \quad$ or ar er

2 macar: see Mongeagudo (2008: 378-379).

4 The verse transmitted by $B$ scans a syllable long. Similar formulas are found without en (CA 5.19, 334.3; CEM 360.8 etc.), while enos can hardly be a late scribal correction.

5 ar: stresses the opposition between me fazedes pesar (v. 2) and poderedes fazer [...] prazer (see next note).

6 p<razer>: Michaëlis' supplement can be counted as certain, given the common antithesis pesar / prazer and the rhetoric here, all of it building towards this word. 


\section{Manuscripts and Works Cited}

$A=$ "Cancioneiro da Ajuda," Palácio Real da Ajuda (Lisboa).

$B=$ Biblioteca Nacional (Lisboa), cod. 10991.

$T o=$ Biblioteca Nacional (Madrid), ms. 10.069 ("El Toledano").

$V=$ Biblioteca Apostolica Vaticana, cod. lat. 4803.

\section{References}

Afonso X, o Sabio (2003): Cantigas de Santa Maria. Edición facsímile do Códice de Toledo (To), Biblioteca Nacional de Madrid (Ms. 10.069) (Santiago de Compostela: Consello da Cultura Galega).

Alvar, C. (1986): "Las poesías de Pero Garcia d'Ambroa", Studi mediolatini e volgari $32,5-112$.

Bertolucci Pizzorusso, V. (1993): "Motivi e registri minoritari nella lirica d'amore galego-portoghese: la cantiga 'de Change",, in O Cantar dos Trobadores, 109-120 (Santiago de Compostela: Xunta de Galicia).

Billy, D. / Canettieri, P./ Pulsoni, C. / Rossell, A. (2003): La lirica galego-portoghese: Saggi di metrica e musica comparata (Roma: Carocci).

Billy, D. (2003): "L'arte delle connessioni nei trobadores", in Billy / Canettieri / Pulsoni / Rossel, 11-111.

$C A=$ Michaëlis (1904).

Canettieri, P. / Pulsoni, C. (2003): "Per uno studio storico-geografico e tipologico dell'imitazione metrica nella lirica galego-portoghese", in Billy / Canettieri / Pulsoni / Rossel, 113-165.

$C E M=$ Lapa, M. Rodrigues (1970) [1965]: Cantigas d'escarnho e de mal dizer dos cancioneiros medievais galego-portugueses. Edição crítica (Vigo: Galáxia).

Cintra, L. F. Lindley (1984) [1959]: A Linguagem dos Foros de Castelo Rodrigo, seu confronto com a dos Foros de Alfaiates, Castelo Bom, Castelo Melhor, Coria, Cáceres e Usagre, contribuição para o estudo do leonês e do galegoportuguês do século xiii (Lisboa: Imprensa Nacional - Casa da Moeda).

Cintra, L. F. Lindley (introd.) (1982): Cancioneiro da Biblioteca Nacional (Colocci-Brancuti), Cód. 10991. Reprodução Facsimilada (Lisboa: Imprensa Nacional - Casa de Moeda). 
Cohen, R. (1987): Thirty-two Cantigas d'amigo of Dom Dinis: Typology of a Portuguese Renunciation (Madison: Hispanic Seminary of Medieval Studies).

Cohen, R. (1996): “Dança Jurídica”, Colóquio-Letras 142: 5-49.

Cohen, R. (2003): 500 Cantigas d'Amigo. Edição crítica / critical edition (Porto: Campo das Letras).

Cohen, R. (forthcoming): Erotic Angles on the Cantigas d'Amigo, Papers of the Medieval Hispanic Research Seminar 64 (London: Department of Hispanic Studies, Queen Mary, University of London).

Cohen, R. / Corriente, F. (2002): “Lelia doura Revisited”, La Corónica 31.1: 1940 .

Corominas, J. (1984-1991): Dicionário crítico-etimológico castellano e hispânico, con la colaboración de José A. Pascual. 6 vols. (Madrid: Gredos).

Correia, A. (1995): "O sistema das coblas doblas na lírica galego-portuguesa", in Paredes, J. (ed.): Medieoevo y Literatura. Actas del V Congreo de la Asociación Hispánica de Literatura Medieval, 75-90 (Granada: Universidad de Granada).

Cotarelo Valledor, A. (1933): “Los hermanos Eans Mariño, poetas gallegos del siglo XIII, Boletin de la Academia Española 20: 5-32.

Cunha, C. Ferreira de (1982): Estudos de Versificação Portuguesa (Séculos XII a XVI) (Paris: Fundação Calouste Gulbenkian, Centro Cultural Português).

CSM = Mettmann, W. (1981) [1959-1972]: Afonso X, o Sábio. Cantigas de Santa Maria. 2 vols. (Vigo: Edicións Xerais de Galicia).

DVPM = Xavier, M. F. / Vicente, G. / Crispim, M. L. (org.) (2002): Dicionário do Verbo Português Medieval: Séculos 12 e 13/14 (Lisboa: Universidade Nova de Lisboa / CLUNL).

Ferrari, A. (1979): "Formazione e struttura del canzoniere portoghese della Biblioteca Nazionale di Lisbona (cod. 10991: Colocci-Brancuti), Premesse codicologiche alla critica del testo (Materiali e note problematiche)", Arquivos do Centro Cultural Português 14: 27-142.

Ferrari, A. (1993). "Cancioneiro da Biblioteca Nacional”, in Lanciani / Tavani (1993), 119-123.

Ferreira, J. de Azevedo (1987): Afonso X. Foro Real. 2 vols. (Lisboa: Instituto Nacional de Investigação Científica). 
Ferreiro, M. (1999): Gramática Histórica Galega. 2 vols. (Santiago de Compostela: Laiovento).

Ferreiro Fernández, M. / Martínez Pereiro, C. P. (1996): Cantigas d'Amigo. Antoloxía (Vigo: Asociación Sócio-Pedagógica Galega).

Ferreiro, M. / Martínez Pereiro, C. P. / Tato Fontaíña, L. (eds.) (2007): Normas de edición para a poesía galego-portuguesa medieval (A Coruña: Universidade da Coruña).

García-Sabell Tormo, T. (1991): Léxico francês nos cancioneiros galegoportugueses: revisión crítica (Vigo: Galáxia).

Gonçalves, E. (1976): La Tavola Colocciana. Autori Portughesi (Paris: Fundação Calouste Gulbenkian, Centro Cultural Português) (= Arquivos do Centro Cultural Português 10 [1976]: 387-448).

Gonçalves, E. (1993): “Diego Moniz”, in Lanciani / Tavani (1993), 216-217.

Huber, J. (1986) [1933]: Gramática do Português Antigo (Lisboa: Fundação Calouste Gulbenkian).

Indini, M. L. (1979): Bernal de Bonaval. Poesie (Bari: Adriatica).

Indini, M.L. (1993): “Airas Moniz d'Asme”, in Lanciani / Tavani (1993), 26.

Lanciani, G. / Tavani, G. (org.) (1993): Dicionário da Literatura Medieval Galega e Portuguesa (Lisboa: Caminho).

Lang, H. R. (1894): Das Liederbuch des Königs Denis von Portugal, zum ersten mal vollständig herausgegeben und mit Einleitung, Anmerkungen und Glossar versehen (Halle a.S.: Max Niemeyer).

Lang, H. R. (1908): “Zum Cancioneiro da Ajuda”, Zeitschrift für romanische Philologie 32: 129-160, 290-399.

Lopes, G. Videira (2002): Cantigas d'Escárnio e Maldizer dos Trovadores e Jograis Galego-Portugueses (Lisboa: Estampa).

Lorenzo, R. (1975-1977): La traducción gallega de la 'Crónica General' y de la 'Crónica de Castilla', edición crítica anotada, con introducción, índice onomástica y glosario. 2 vols. (Orense: Instituto de Estudios Orensanos 'Padre Feijoo').

Machado, E. Pacheco and Machado, J. P. (1949-1964): Cancioneiro da Biblioteca Nacional, Antigo Colocci-Brancuti, leitura, comentários e glossário. 8 vols. (Lisboa: 'Revista de Portugal'). 
Rip Cohen

Madvig, I. N. (1871-84) [1967]: Adversaria Critica in Auctores Graecos et Latinos (Hauniae: sumptibus Librariae Gyldendalianae).

Michaëlis de Vasconcellos, C. (1904) [rpt. 1990, with Michaëlis 1920]: Cancioneiro da Ajuda. Edição critica e commentada. 2 vols. (Halle a.S.: Max Niemeyer).

Michaëlis de Vasconcellos, C. (1920): "Glossário do Cancioneiro da Ajuda”, Revista Lusitana 23: 1-95.

Miranda, J. C. Ribeiro (2004): Aurs Mesclatz ab Argen: sobre a primeira geração de trovadores galego-portugueses (Porto: Guarecer).

Molteni, E. (1880): Il canzoniere portoghese Colocci-Brancuti, pubblicato nelle parti che completano il codice vaticano 4803 (Halle a.S.: Max Niemeyer).

Monteagudo, H. (2008): Letras primeiras: O foral de Caldelas, a emerxencia da escrita en galego e os primórdios da lírica trobadoresca (A Coruña: Fundación Pedro Barrié da la Maza).

Muniz, M. R. Coelho (2002): “A rebeldia de um amante: as cantigas de amor do trovador Osoiro Anes”, Estudos Galegos 3: 99-112.

Niermeyer, J. F. [1993] (1976): Mediae Latinitatis Lexicon Minus (Leiden / New York / Köln: E. J. Brill).

Nobiling, O. (1907): "Zu Text und Interpretation des 'Cancioneiro da Ajuda"”, Romanische Forschungen 33 (=Mélanges Chabaneau), 339-385.

Nobiling, O. (1908-1909) [Review of Michaëlis 1904]: Archiv für das Studium der neueren Sprachen und Literaturen 121: 197-208; 122: 193-206.

Nunes, J. J. (1921) [1906]: Crestomatia arcaica, excertos da literatura portuguesa desde o que de mais antigo se conhece até ao século XVI, acompanhados de introdução gramatical, notas e glossário (Lisboa: Livraria Clássica).

Nunes, J. J. (1973) [1926-1928]. Cantigas d'amigo dos trovadores galegoportugueses. Edição crítica acompanhada de introdução, comentário, variantes, e glossário. 3 vols. (Coimbra: Imprensa da Universidade).

Nunes, J. J. (1989) [1919]: Compêndio da gramática histórica portuguesa (Fonética e morfologia) (Lisboa: Livraria Clássica Editora).

$O L D=$ Glare, P. G. W. (ed.) (1983): Oxford Latin Dictionary (Oxford: Clarendon).

Oliveira, A. Resende de (1994): Depois do Espectáculo Trovadoresco: a estrutura dos cancioneiros peninsulares e as recolhas dos séculos XIII e XIV (Lisboa: Colibri). 
Panunzio, S. [1992] (1967): Pero da Ponte. Poesias (Vigo: Galaxia).

Parkinson, S. (2006): "Rules of elision and hiatus in the Galician-Portuguese lyric: the view from the Cantigas de Santa Maria", La Coronica 34.2: 113-133.

Pellegrini, S. (1928): Auswahl altportugiesischer Lieder (Halle: Max Niemeyer).

Pereiro, C. P. Martínez (1992): As cantigas de Fernan Paez de Tamalancos. Edición crítica con introdución, notas e glosário (Santiago de Compostela: Laiovento).

Rep. $=$ Tavani, G. (1967): Repertorio metrico della lirica galego-portoghese $($ Roma: Edizioni dell' Ateneo).

REW = Meyer-Lübke, W. [1992] (1934): Romanisches Etymologisches Wörterbuch (Heidelberg: Carl Winter Universitätsverlag).

Rey Somoza, A. (1998): “A obra de Diego Moniz, edición y anotación de textos", en Chas Aguión, A. / Pampín Barral, M. / Pena, N. / Campos, B. / Parrilla García, M. C. / Campos, M. (coord.), Actas del I Congreso de Jóvenes Filólogos (A Coruña, 25-28 de septiembre de 1996). II, 551-564 (A Coruña: Universidade da Coruña).

Smith, C. (1986): Poema de Mio Cid (Madrid: Cátedra).

Stegagno Picchio, L. (1968): Martin Moya. Le Poesie, edizione critica, introduzione, commento e glossário (Roma: Edizioni dell' Ateneo).

Stegagno Picchio. L. (1982): La Méthode philologique. Écrits sur la littérature portugaise. 2 vols. (Paris: Fundação Calouste Gulbenkian, Centro Cultural Português).

TMILG = Varela Barreiro, X. (dir.) (2004-): Tesouro Medieval Informatizado da Lingua Galega (Santiago de Compostela: Instituto da Lingua Galega). Accessed at http://ilg.usc.es/tmilg.

Weiss, M. (2009): Outline of the Historical and Comparative Grammar of Latin (Ann Arbor: Beech Stave Press).

Williams, E. B. (1938): From Latin to Portuguese (Philadelphia: University of Pennsylvania Press).

Vallín, G. (1995): Las cantigas de Pay Soarez de Taveirós. Estudio histórico y edición (Bellaterra / Barcelona: Facultad de Letras, Universidad Autónoma de Barcelona).

Zilli, C. (1977): Johan Baveca. Poesie (Bari: Adriatica). 


\title{
Appendix: An English Translation
}

\author{
Airas Moniz d'Asme 1 \\ Since it does me no good to love my lady \\ So much, or to serve her, \\ Or to know how to neatly hide \\ The love I feel, and keep it secret \\ From her, who makes me lose my mind- \\ Since they haven't caught on yet, \\ I won't keep her hidden anymore: \\ At least they'll know who's wronging me:
}

The one who has the greatest beauty

Of all the women to be seen in the world

And a much more $<$ pleasing voice $>$

Than all the ladies you hear speaking.

I needn't proclaim her anymore,

Since anyone can understand;

I will not say her name again,

Since I've named her already.

And whoever wants to trek around

The world and turn it upside down

Can find her very quickly,

Because, to tell you the whole truth,

She hardly has the kind of beauty

That could be concealed like that.

Just from the way I've sketched her out

They will find her, that's for sure.

Those that used to bother me-

To them I have revealed my lady;

Now they should let me rest

(Since I couldn't put up with them)

Because I told them who she is,

Since she would not please me,

And I think I've taken fine revenge

By shaming her openly. 


\section{Airas Moniz d' Asme 2}

"My lady, I’ve come to ask, By God, that you think Of me, whom you have been And still are leading on. And I think I'm being shamed. If you please, you ought To respect my beard, Which is used to being respected, And not do it offense."

"Sir, you will never hear me Do it any offense,

But let's leave that alone

$\cdots$

And as to what you sayI'm not even thinking of loving you Nor will I think it, in my view, Any more than what you see."

"My lady, I will tell you What you should do about me: What I always loved you forConsider it as nothing, And still I'll always serve you. Since you've shamed me now, Please do what I would like:

Give me something else, and I'll go And don't keep me lingering."

"Sir, I'll give you no such thing, But if you complain, I will give you good advice:

Go, since you're tarrying, For why should I make you linger Where you won't get anything? Still, I will be yearning For you, and I'll have to endure it Until you come back again.” 
"My lady, as I see it,

It would be more fitting

For you to want to do for me

What I would do for you.

For I'd never, for such a trifle,

Keep you waiting for my sake,

But I cannot find a lady

Who does as much what I would like

As I would do what she likes."

\section{Diego Moniz 1}

God! how little I knew

What happiness I was living in

When I was with my lady,

And how much I complained

Of her (for she didn't think

Of me) and wasn't thankful

To God for the favor she did me

Just by letting me see

Her amazing beauty.

How completely crazed I was

When I was not fully pleased

Just to live around such a lady,

And always wanted more bliss;

And now it would please me enough,

But who would give me this?-

This bliss, that didn't grip me:

I wish now that I had no better,

And could live with such pleasure!

But then again my heart

Would kill me, a heart very

Full of folly and of love,

That nearly killed me before;

When I gazed at my lady

It would make me suffer so

That I didn't have a clue 
About myself, or what to do

To get more bliss from her.

But if I could ever recover

The happiness that I was in,

I would know how to put up with

Her love, and I'd remember

That I couldn't live without her

When I went elsewhere to live,

I desired her so much;

But now, what with this terror,

I'd put up with it very well.

\section{Diego Moniz 2}

If my lady knew how much I would like

To die since I don't have her, then I wouldn't die,

For, though she doesn't love me, she would show me love

To make me live, despite myself

When what I really wanted was death.

And if they went and told her that I'm saying this, I know that my lady would come and seek me out

\section{Osoir’ Anes 1}

Love took me by force

And made me love someone who's never loved;

And he did me wrong, like an enemy,

When he sent me back to such a lady;

And I see that I played it wrong

By going back to a lady like that-

Who doesn't know what loving is,

But knows how to make a man feel pain.

Now I'm forced to go on living

Without pleasure in this world, 
For I could never feel pleasure

From me or anything, since I was hers,

But only from her. And what will I do?

Why do I ask? Since I know:

I will live, if she's kind to me,

Or die if she doesn't love me.

Anyone at all can see this,

Especially if they know my life:

That I don't have the mind or strength

To shield myself from a lady,

The tamest one I've ever seen

Since I was born, and the most mild.

Tell me if I'm not bad off,

Since I can't defend myself!

Because I'm so much in her sway

That if I want to act another way

I will not be able to,

Unless God gives me the power

Over her, whom I have served,

That He gave her over me,

Who could never love anyone else

But her, though she brings me pain.

\section{Osoir' Anes 2}

It's time for me to go away

From my lady, for it's been a while

That I've served her, and I've lost

Her love, and so I will go.

But first I'll say this to her:

'Lady, did I deserve this?

For wasn't I even worse off

After I won your love?

And you'll be forced to feel

How much you will miss me,

And you will see, I know,

That I can live without you. 
And you will say of me:

"Poor girl! Why did I lose him?

And what will I do when he goes

Elsewhere to serve another lady?

I will miss him like crazy-

I can't imagine how much,

Or how I can live without him.

He'll go away from me in a huff

And they'll think I was a fool

For not being kind to such a man.

Any lady who takes him in

Might end up falling out with me.

Every time I get angry at her

(So I think) and curse her out-

If my neighbor takes him away

From me, and seduces him-

A bad neighbor is what she'll be.

But she won't have to feel my wrath,

'Cause I don't want to take her boy,

But I will never let mine go.

\section{Osoir' Anes 3}

I, who found a new lady,

Couldn't keep myself from pain,

Since she's never known how to love-

The lady I will tell you about,

But still I'll tell her this one time

To do what she has never done.

A lady that knows how to love a man

Will never be badly served by that,

For I've seen a fine lady become

A thousand times better because of love,

And so I will tell her this one time

To do what she has never done. 


\section{Osoir' Anes 4}

I thought that my heart

Could never force me,

(Since it had let me out of jail)

And go back there with me,

And yet a new love has forced me,

I am forced by a new lady

And I think she's going to kill me.

And since a lady let me go

Just like that, ever since then

I really thought I never could

Find another one,

But my eyes have forced me

And the beauty of hers

And her grace, and a song

That I heard when I saw her,

Her long hair down, singing a tune-

I should have died there and then,

Rather than suffer the kind of pain

That I suffer, for I've never seen

Anything worse, and so I'm afraid

To die, or to show her my love.

\section{Osoir' Anes 5}

And why do you hate me,

O best of all women I've ever seen?

I think that you gain nothing

From the pain I feel because of you;

Because of your anger towards me

I've suffered such hard days;

It's only right,

Since you keep me from the thing

That I have loved most,

And that is you. And surely you know

I wasn't asking for that much love, 
And if you think otherwise

You're really wronging me, And please do not do that,

For thanks to you I'll be destroyed.

I have this comfort,

That I won't last long

If you're not kind to me.

Lots of people ask me

Why I feel such pain

And I really get annoyed

At whoever seeks me out.

Then, against my will, I must

Find a way to defend myself

And be

On guard against them, and grumble,

And go around there warily.

Then, when I lie down,

Keen yearning comes over me,

But at least I'm relieved

That I don't have to talk to them.

I lie far away from them, alone,

So they cannot hear me groan.

Such love

You can truly swear

No man who ever lived has borne.

One thing I will swear to you

And you ought to believe it:

That I would never love again

If I survive this time;

Since you, whom I loved,

Have destroyed me for no reason.

What pleasure

Do you feel in taking from me

My life, that was to serve you.

For He that created me

Would not take me now, 
And, alive, I couldn't take

So much suffering,

For I would not survive.

Once 1 lie down,

Loving

Your beauty

Ought to be enough for me.

\section{Osoir' Anes 6}

You, my lady, who do not care

To listen to me or do me a favor

Since God didn't want it, or my fortune

Against which I never could defend myself-

I want to tell you of my yearning:

Because of you I'm in pain worse than death;

If God doesn't save me, or my common sense,

I will be lost, and in losing myself you

Will be lost to me, since so much pain

As I suffer because of you endures.

And yet I cannot be angry at you,

Although you make me live in longing

And I must take as a favor

All the pain you make me feel.

All this I do, and I don't do what's wise,

Since you won't show me any gratitude.

\section{Osoir' Anes 7}

I am so afraid of my lady

That I never dare to tell her anything

And look what it is that causes my fear:

Someone who won't either kill or capture

Or hurl insults, or answer angrily,

Or gaze... 


\section{Osoir’ Anes 8}

By God, my lovely lady,

Although you cause me pain

I must always long for you

All the days of my life,

For you can still make me feel

$<$ Pleasure $>$ when you please. 